Sains Malaysiana 50(11)(2021): 3355-3363

http://doi.org/10.17576/jsm-2021-5011-19

\title{
Electrocardiographic (ECG) Characteristics among Malaysian Athletes
}

(Pencirian Elektrokardiografi (ECG) dalam Kalangan Atlet Malaysia)

\author{
Mohamad Shariff A Hamid*, Sazlina Shariff Ghazali, Ahmad Munawwar Helmi Salim, Kamarul \\ HASHIMY HUSSEIN, ZULKARNAIN JAAFAR \& SAMIHAH ABDUL KARIM
}

\begin{abstract}
The electrocardiogram (ECG) is a graphic representation of the heart's electrical activity. Although it has some limitations as a diagnostic or prognostic tool, it contains a wealth of information necessary for the proper care of a patient with a potential cardiovascular disease. Understanding the ECG changes among athletes would allow medical practitioners to distinguish between normal physiological adaptations and abnormal changes. However, there is limited data on the ECG characteristics among multi-ethnic athletes such as in Malaysia. This study aimed to determine the ECG characteristics and its associated factors among Malaysian national athletes. Malaysian national athletes annual preparticipation medical records were retrieved. Information on sociodemographic, sports and medical history including the 12-lead resting ECG tracings were extracted. ECG were assessed and categorised into normal, physiological adaptation changes, and abnormal ECG using the standardised 'Seattle criteria'. Differences in ECG characteristics between genders, ethnic background, and type of sports was investigated. Additionally, factors associated with the ECG characteristics were assessed using multiple logistic regression. Majority of Malaysian national athletes had physiological adaptation ECG changes (61\%). The most frequent changes were early repolarization, sinus bradycardia and isolated left ventricular hypertrophy. We found significantly higher prevalence of physiological adaptation changes among men $\left(\chi^{2}(2,371)=18.9 ; \mathrm{p}=0.001\right)$ and athletes of Chinese ethnicity (both genders) $\left(\chi^{2}(2,356)=13.8 ; \mathrm{p}=0.002\right)$. Factors associated with physiological ECG changes were men (OR=2.67; $95 \% C I=1.68,4.27 ; \mathrm{p}<0.001)$ and Chinese ethnicity $(O R=2.92 ; 95 \% C I=1.68,4.27 ; \mathrm{p}=0.039)$. Most athletes had physiological adaptation ECG changes which were significantly associated with male gender and Chinese ethnicity. This information would facilitate the development of a specific guideline in interpreting ECG among Malaysian athletes.
\end{abstract}

Keywords: Athletes' heart; electrocardiogram; patterns; physiological adaptation

ABSTRAK

Elektrokardiogram (ECG) adalah gambaran grafik aktiviti elektrik jantung. Walaupun ia mempunyai beberapa batasan sebagai alat diagnostik ataupun prognostik, ia mengandungi pelbagai maklumat yang diperlukan dalam penjagaan pesakit yang berpotensi mengidap penyakit kardiovaskular. Memahami perubahan elektrokardiografi (ECG) dalam kalangan atlet akan membolehkan para pengamal perubatan membezakan antara perubahan akibat penyesuaian fisiologi normal dan perubahan yang tidak normal. Walau bagaimanapun, terdapat data terhad mengenai ciri-ciri ECG dalam kalangan atlet berbilang kaum seperti di Malaysia. Kajian ini bertujuan untuk menentukan ciri-ciri ECG dan faktor yang berkaitan dalam kalangan atlet kebangsaan Malaysia. Rekod perubatan pemeriksaan saringan kesihatan tahunan atlet kebangsaan Malaysia diperoleh untuk penilaian. Maklumat berkaitan sosiodemografi, sukan dan sejarah perubatan termasuk rekod ECG (sewaktu rehat) diekstrak. ECG dinilai dan dikategorikan kepada perubahan adaptasi fisiologi yang normal dan tidak normal ECG menggunakan 'Kriteria Seattle' yang diseragamkan. Perbezaan ciri ECG antara jantina, latar belakang etnik dan jenis sukan diselidiki. Di samping itu, faktor yang dikaitkan dengan ciri-ciri ECG dinilai dengan menggunakan regresi logistik berganda. Majoriti (61\%) atlet kebangsaan Malaysia mempunyai perubahan penyesuaian fisiologi ECG terhadap sukan. Perubahan paling kerap ialah pengutuban semula awal, bradikardia sinus dan hipertrofi ventrikel kiri. Perubahan ketara perubahan penyesuaian fisiologi didapati dalam kalangan atlet lelaki $\left(\chi^{2}(2,371)=18.9 ; p=0.001\right)$ dan atlet etnik Cina (lelaki dan wanita) $\left(\chi^{2}(2,356)=13.8 ; p=0.002\right)$. Faktor yang dikaitkan dengan perubahan fizikal fisiologi ialah lelaki $(O R=2.67,95 \% C I=1.68,4.27 ; p<0.001)$ dan etnik Cina $(O R=2.92 ; 95 \% C I=1.68,4.27 ; p=$ 0.039). Kebanyakan atlet mempunyai perubahan penyesuaian fisiologi perubahan ECG yang dikaitkan dengan jantina lelaki dan etnik Cina. Maklumat ini akan memudahkan perkembangan garis panduan khusus dalam menafsirkan ECG dalam kalangan atlet Malaysia.

Kata kunci: Corak; elektrokardiogram; jantung atlet; penyesuaian fisiologi 


\section{INTRODUCTION}

Electrocardiographic (ECG) alterations are common among athletes. In most cases, the ECG changes observed reflected on benign structural and electrical remodelling of the heart in response to long-term exposure to regular and sustained physical training (Drezner et al. 2013b). This phenomenon is also known as the athlete's heart. In some cases, the ECG changes may represent an underlying inherited or congenital cardiovascular abnormality that might lead to sudden cardiac death (SCD) (Harmon et al. 2011; Maron et al. 2003). Early detection of such diseases might prevent occurrence of SCD during physical activities. A systematic pre-participation screening that includes 12-lead ECG assessment has led to $89 \%$ decrease in the incidence of SCD (Corrado et al. 2006).

The extent of cardiac morphological and electrical changes in response to regular exercise are affected by several factors including the athletes' age, gender, ethnicity and type of sports (D'Silva \& Sharma 2014; Karagjozova et al. 2017; Papadakis et al. 2012). Physiological ECG alterations were more prevalent among male athletes and among athletes of African/Caribbean ethnicity (Magalski et al. 2008; Papadakis et al. 2012). They reported significant difference in the proportion of ECG changes between athletes of different ages and type of sports (Pelliccia et al. 2007). Lower prevalence of ECG changes were reported among young competitive athletes in Asia (Ma et al. 2007). Understanding the ECG changes among athletes would allow medical practitioners to distinguish between normal physiological adaptations and abnormal changes. This is important for further action to exclude or confirm underlying cardiovascular conditions associated with SCD. In clinical practice, one of the methods to assess ECG tracings among athletes are done using the 'Seattle Criteria' (Drezner et al. 2013a). A standard comprehensive guideline and online training module for physicians using the Seattle Criteria is available at no cost through the British Medical Journal learning platform (BMJ Learning). This provides an important platform to improve the quality and standard of ECG interpretations for athletes.

Previous studies on ECG characteristics among athletes mostly involved athletes of Caucasian background (Magalski et al. 2008; Papadakis et al. 2012; Rawlins et al. 2009; Waase et al. 2018). However, Malaysia is a multi-ethnic country with a total population of 32.6 million people (Department of Statistics Malaysia 2019). The Malays, Chinese and Indians ethnicities made up almost $>80 \%$ of the total Malaysia population.

At the National Sports Institute (NSI) of Malaysia, athletes are required to complete annual pre-participation assessment. During these assessments, brief clinical history and structured physical examination were performed. Additionally, a resting 12-lead ECG is also routinely conducted. Currently, there is limited data on
ECG characteristics among the multi-ethnic Malaysian athletes (Lim et al. 2017). Hence, this study aimed to determine the ECG characteristics of Malaysian athletes in NSI using the 2012 'Seattle Criteria' recommendations for 12-lead ECG interpretations (Drezner et al. 2013a). Additionally, factors associated with ECG characteristics were investigated.

\section{MATERIALS AND METHODS}

A retrospective medical records review was performed from 2 January to 31 December 2017 at the NSI Clinic, Kuala Lumpur, Malaysia. The athlete's pre-participation medical records from January 2015 to December 2016 were reviewed. Athletes' sociodemographic (date of birth, gender, education level, marital status, occupation), height, weight, type of sports, blood pressures (diastolic and systolic) and resting ECG tracings were extracted.

Age was defined as the athlete's age at the time of pre-participation assessment based on the date of birth. Body mass index (BMI) was calculated with the weight $(\mathrm{kg})$ divided by the height squared $\left(\mathrm{m}^{2}\right)$. The classification of BMI was based on the Malaysia Clinical Practice Guideline on Obesity (Clinical Practice Guidelines on Obesity 2004). The various sports were grouped into classes based on the peak static and dynamic components of the sports as described by Mitchell et al. (2005). Each sport was categorised into low, moderate and high level of intensity of static and dynamic exercise.

All resting 12-lead ECGs were performed by trained paramedics (medical officer assistants or staff nurses) with the athlete in the supine position. ECGs were performed using the MAC1600 ECG Analysis System (GE Medical System, USA) with the paper speed set at $25 \mathrm{~mm} / \mathrm{s}$ and amplification of $0.1 \mathrm{mV}$ (Friedman 1985). All ECG tracings were scanned and made anonymized (athlete's name and identification number were removed) before sending for assessment by 2 sports physicians (ZJ and SAK). Both assessors had successfully completed the BMJ Learning 'ECG interpretation in athletes' online training module (BMJ Learning) prior to the study commencement. A standardised ECG reporting form was created to document ECG characteristics based on the 'Seattle Criteria'. The 'Seattle Criteria' was introduced in 2012 at the ECG interpretation summit to improve the specificity of the ECG when used as a screening tool for athletes (Lisman 2016). These criteria divide ECG characteristics into 2 categories: adaptive and benign training-induced ECG that need no further workup (normal physiological changes), or abnormal ECG that could indicate underlying pathology therefore require further evaluation (Drezner et al. 2013a, 2013b).

Data analysis was performed using the Statistical Package for Social Sciences Version 25.0 (SPSS Inc, Chicago, IL, USA), and a $p$ value of $<0.05$ was considered significant. Continuous variables were expressed as mean 
and standard deviation or median and interquartile range depending on normality of data distribution. Categorical variables were described as absolute numbers and percentages. Differences between and within genders were analysed using Chi-square and Kruskal-Wallis tests for categorical and continuous data, respectively. The associations between ECG changes and type of sports and ethnicity were assessed using Chi-square tests. Comparisons between normal and physiological adaptations changes were assessed using the multiple logistic regression using enter methods. Prior to logistic regression analysis relevant data were assessed to ensure all assumptions were met, including multicollinearity. In essence, multicollinearity is a statistical phenomenon in which predictor variables are highly correlated (Fields 2009). Multicollinearity cause unstable estimates and inaccurate variances which affects variances of the parameter estimates, and consequently incorrect inferences about relationships between variables (Habshah et al. 2013).

We did not include abnormal changes in view of the small proportion. The findings of logistic regression were presented as odds ratio (OR) and 95\% confidence interval (CI). Ethical approvals were obtained from the University of Malaya Medical Centre Ethics Committee (MECID. No. 20152-1023) and the National Institute of Sports of Malaysia (ISNRP-016-2015).

\section{RESULTS}

A total of 371 athletes' medical pre-participation records were retrieved in this study. Athletes sociodemographic characteristics are displayed in Table 1.

TABLE 1. Participants sociodemographic and anthropometric characteristics $(n=371)$

\begin{tabular}{|c|c|c|}
\hline Variables & Median (IQR) [Range] & Frequency $(\%)$ \\
\hline Age (year) & 20.0 (IQR 5.0) [11 to 58] & \\
\hline Weight $^{\mathrm{a}}(\mathrm{kg})$ & $63.2(\mathrm{IQR} 19.1)$ [35.9 to 121.6$]$ & \\
\hline $\operatorname{Height}^{\mathrm{b}}(\mathrm{cm})$ & 167.0 (IQR 13.0$)$ [144 to 197.0$]$ & \\
\hline $\mathrm{BSA}^{\mathrm{b}}\left(\mathrm{m}^{2}\right)$ & 1.7 (IQR 0.3) [1.22 to 2.40$]$ & \\
\hline $\mathrm{BMI}^{\mathrm{b}}$ & 22.1 (IQR 4.2) [15.29 to 44.14] & \\
\hline Underweight & & $22(5.9)$ \\
\hline Normal weight & & $191(51.5)$ \\
\hline Pre-obese & & $94(25.3)$ \\
\hline Obese I & & $38(10.2)$ \\
\hline Obese II & & $7(1.9)$ \\
\hline Obese III & & $19(5.1)$ \\
\hline \multicolumn{3}{|l|}{ Gender } \\
\hline Men & & $183(49.3)$ \\
\hline Women & & $188(50.7)$ \\
\hline \multicolumn{3}{|l|}{ Ethnic background } \\
\hline Malay & & $208(56.1)$ \\
\hline Chinese & & $144(38.8)$ \\
\hline Indian & & $13(3.5)$ \\
\hline Others & & $6(1.6)$ \\
\hline \multicolumn{3}{|l|}{ Education level } \\
\hline Primary & & $6(1.6)$ \\
\hline Secondary & & $144(38.8)$ \\
\hline Tertiary & & $107(28.9)$ \\
\hline Not stated & & $114(30.7)$ \\
\hline \multicolumn{3}{|l|}{ Occupation } \\
\hline Athlete & & $84(22.6)$ \\
\hline Student & & $172(46.4)$ \\
\hline Employed & & $29(7.8)$ \\
\hline Not stated & & $86(24.1)$ \\
\hline \multicolumn{3}{|l|}{ Marital status } \\
\hline Single & & $316(85.2)$ \\
\hline Married & & $18(4.9)$ \\
\hline Not stated & & $37(10.0)$ \\
\hline
\end{tabular}

BMI = body mass index; BSA=body surface area

${ }^{\mathrm{a}} 14$ missing data; ${ }^{\mathrm{b}} 16$ missing data 
Table 2 compared the health parameters between men and women. Men were significantly taller, heavier, has higher BSA \& BMI and higher systolic blood pressure compared to women $(p<0.05)$. However, there was no significant difference in age between genders. There was no significant differences in age, weight, height and BMI within gender among all ethnicities $(p>0.05)$. Athletes from 34 different sports were represented in this study. Majority $(61.8 \%)$ of athletes in this study were in the low-static sports class (Table 3 ).

TABLE 2. Comparison of health parameters according to gender

\begin{tabular}{|c|c|c|c|c|}
\hline \multirow{2}{*}{ Characteristics } & \multicolumn{2}{|c|}{ Gender } & \multirow[b]{2}{*}{$\mathrm{z}$} & \multirow[b]{2}{*}{$p$} \\
\hline & Men & Women & & \\
\hline Age (years) & $21.0(5.0)$ & $20.0(5.0)$ & 0.96 & 0.382 \\
\hline Height $(\mathrm{cm})^{\mathrm{a}}$ & $172.0(11.6)$ & $163.0(9.8)$ & 117.50 & $<0.001^{* *}$ \\
\hline Weight $(\mathrm{kg})^{\mathrm{b}}$ & $68.8(18.0)$ & $57.8(13.0)$ & 51.10 & $<0.001^{* *}$ \\
\hline $\operatorname{BSA}\left(m^{2}\right)^{b}$ & $1.8(0.3)$ & $1.6(0.2)$ & 58.60 & $<0.001^{* *}$ \\
\hline $\operatorname{BMI}\left(\mathrm{kg} / \mathrm{m}^{2}\right)^{\mathrm{b}}$ & $22.7(4.4)$ & $21.4(4.2)$ & 11.60 & $0.001^{* *}$ \\
\hline Systolic blood pressure (mmHg) & $115.0(18.0)$ & $105.0(16.0)$ & 29.70 & $<0.001^{* *}$ \\
\hline Diastolic blood pressure (mmHg) & $67.0(13.3)$ & $67.0(11.0)$ & 0.40 & 0.509 \\
\hline Pulse rate (bpm) & $66.5(13.0)$ & $71.0(16.0)$ & 6.50 & 0.011 \\
\hline
\end{tabular}

$\mathrm{BMI}=$ body mass index BSA=body surface area $\mathrm{bpm}=$ beat per minute

${ }^{\mathrm{a}} 14$ missing data; ${ }^{\mathrm{b}} 16$ missing data

${ }^{*} \mathrm{p}<0.05,{ }^{* *} \mathrm{p}<0.01$

TABLE 3. Classification of sports based on static and dynamic components $(n=371)$

\begin{tabular}{|c|c|c|c|c|}
\hline \multirow[b]{2}{*}{ Static component } & & \multicolumn{3}{|c|}{ Dynamic component } \\
\hline & & Low & Moderate & High \\
\hline & High & $36(9.7 \%)$ & $2(0.5 \%)$ & $3(0.8 \%)$ \\
\hline & & $\begin{array}{l}\text { Gymnastic, karate, } \\
\text { silat, waterski, wushu }\end{array}$ & Bodybuilding & Boxing \\
\hline & Moderate & $23(6.2 \%)$ & $45(12.1 \%)$ & $33(8.9 \%)$ \\
\hline & & $\begin{array}{l}\text { Archery, diving, } \\
\text { equestrian }\end{array}$ & $\begin{array}{l}\text { Athletic, fencing, rugby, } \\
\text { synchronised swimming }\end{array}$ & Ice hockey \\
\hline & Low & $67(18.1 \%)$ & $54(14.6 \%)$ & $108(29.1 \%)$ \\
\hline & & $\begin{array}{l}\text { Petanque, bowling, } \\
\text { golf, } \\
\text { lawn ball, shooting }\end{array}$ & $\begin{array}{l}\text { Dodgeball, softball, table } \\
\text { tennis, volleyball }\end{array}$ & $\begin{array}{c}\text { Sepak takraw, badminton, } \\
\text { field hockey, soccer, } \\
\text { squash }\end{array}$ \\
\hline
\end{tabular}


A total of $356(96 \%)$ ECGs assessed were considered normal (completely normal ECG and physiological adaptation ECG changes). Of the normal ECG, physiological adaptations changes were seen in 226 athletes $(61 \%)$, with the remaining $130(35 \%)$ were completely normal ECG. The 3 most frequent physiological adaptations ECG changes in this study were early repolarization pattern $(n=171 / 46.1 \%)$, sinus bradycardia $(n=132 / 35.6 \%)$ and isolated QRS voltage criteria for left ventricular hypertrophy $(\mathrm{n}=69 / 18.6 \%)$ (Table 4$)$.

TABLE 4. ECG physiological adaptations changes $(n=226)$

\begin{tabular}{lcc}
\hline Physiological ECG changes & Frequency & $\%$ \\
\hline Early repolarization & 171 & 46.1 \\
Sinus bradycardia & 132 & 35.6 \\
Isolated QRS LVH & 69 & 18.6 \\
Sinus arrhythmia & 35 & 9.4 \\
Incomplete RBBB & 17 & 4.6 \\
$1^{\text {st degree AV block }}$ & 8 & 2.2 \\
Ectopic atrial & 5 & 1.3 \\
Junctional escape & 4 & 1.1 \\
Mobitz Type 1 AV block & 1 & 0.3 \\
\hline
\end{tabular}

$\mathrm{LVH}=$ left ventricular hypertrophy; $\mathrm{RBBB}=$ right bundle branch block; $\mathrm{AV}=$ atrioventricular

Most athletes $(n=143 / 63.3 \%)$ with physiological adaptations ECG changes had 2 or more characteristics in their tracings. The prevalence of normal physiological changes were significantly higher among men compared to women $\left(\chi^{2}(2,371)=18.9 ; p=0.001\right)$. Significantly higher proportion of athletes of Chinese ethnicity (both men and women) had normal physiological ECG changes compared to athletes of other ethnic background $\left(\chi^{2}(2,356)=13.8\right.$; $p=0.001)$ (Table 5).

TABLE 5. Gender and ethnicity association with physiological adaptations ECG changes $(n=356)$

\begin{tabular}{|c|c|c|c|}
\hline \multirow[b]{2}{*}{ Variables } & \multicolumn{2}{|r|}{ ECG Changes } & \multirow[b]{2}{*}{$p$} \\
\hline & $\begin{array}{c}\text { Completely } \\
\text { Normal }\end{array}$ & Physiological adaptation & \\
\hline \multicolumn{4}{|l|}{ Gender } \\
\hline Men & $48(27.1)$ & $129(72.9)$ & \multirow{2}{*}{$<0.001^{* *}$} \\
\hline Women & $82(45.8)$ & $97(54.2)$ & \\
\hline \multicolumn{4}{|l|}{ Ethnicity } \\
\hline & $87(43.7)$ & $112(56.3)$ & \multirow{3}{*}{$0.002 * *$} \\
\hline Chinese & $34(24.6)$ & $104(75.4)$ & \\
\hline others & $9(47.4)$ & $10(52.6)$ & \\
\hline
\end{tabular}


Only 15 (4\%) athletes had abnormal ECG changes. Thirteen had single abnormal ECG changes and 3 had more than 1 abnormal ECG changes. Of these, the frequent abnormal ECG changes observed was long QT interval followed by T-wave inversion, pathological Q-wave and right ventricular hypertrophy (Table 6).

TABLE 6. Abnormal ECG changes $(\mathrm{n}=371)$

\begin{tabular}{lcc}
\hline Abnormal ECG changes $(\mathrm{n}=15)$ & Frequency & $\%$ \\
\hline Long QT & 7 & 1.9 \\
T-wave inversion & 3 & 0.8 \\
Pathological Q-wave & 2 & 0.5 \\
R ventricular hypertrophy & 2 & 0.3 \\
Complete LBBB & 1 & 0.3 \\
Complete RBBB & 1 & 0.3 \\
Mobitz type II & 1 & 0.3 \\
Ventricular pre-excitation & 1 & 0.3 \\
Epsilon wave & 1 & 0.3 \\
\hline
\end{tabular}

LBBBB=left bundle branch block; RBBB=right bundle branch block

There were significant associations between physiological adaptations ECG changes with men $(\mathrm{OR}=2.67 ; 95 \% \mathrm{CI}=1.68,4.27 ; p<0.001)$ and Chinese athletes $(\mathrm{OR}=2.92 ; 95 \% \mathrm{CI}=1.68,4.27 ; p=0.39)$ (Table
7). There were no significant association between the physiological adaptation's ECG changes and age nor types of sports. There was no multicollinearity between the variables.

TABLE 7. Associations between physiological adaptations ECG changes and age, gender, ethnicity, and sports classification $(\mathrm{N}=356)$

\begin{tabular}{|c|c|c|c|}
\hline Variables & $\beta(\mathrm{SE})$ & Odds ratio $(95 \% \mathrm{CI})$ & $P$-Value \\
\hline \multicolumn{4}{|l|}{ Age } \\
\hline$<18$ years & $0.04(0.51)$ & $1.04(0.38,2.82)$ & 0.941 \\
\hline $18-29$ years & $0.28(0.47)$ & $1.33(0.53,3.35)$ & 0.550 \\
\hline$\geq 30$ years & Ref & & \\
\hline \multicolumn{4}{|l|}{ Gender } \\
\hline Men & $0.98(0.24)$ & $2.67(1.68,4.27)$ & $<0.001 * *$ \\
\hline Women & Ref & & \\
\hline \multicolumn{4}{|l|}{ Ethnicity } \\
\hline Malay & $0.10(0.50)$ & $1.10(0.42,2.91)$ & 0.840 \\
\hline Chinese & $1.07(0.52)$ & $2.92(1.06,8.07)$ & $0.039 *$ \\
\hline Indians and others & Ref & & \\
\hline \multicolumn{4}{|l|}{ Sports classification } \\
\hline Low static & $0.16(0.36)$ & $1.17(0.57,2.38)$ & 0.669 \\
\hline Moderate static & $0.42(0.40)$ & $1.51(0.69,3.34)$ & 0.304 \\
\hline High static & Ref & & \\
\hline
\end{tabular}

$\mathrm{Ref}=$ reference group $\mathrm{CI}=$ confidence interval; statistical significance $=\mathrm{p}<0.05 ;$ Chi-square $=4.64, \mathrm{p}=0.704 ; \mathrm{R}^{2}=0.124 * p<0.05, * * p<0.01$ 


\section{DISCUSSION}

Majority of highly trained athletes in this study had normal ECG. The prevalence of normal ECG of $96 \%$ in this study was comparable to those reported by previous studies. Normal ECG or ECG with minor alteration prevalence ranges between $88.2 \%$ and $95.5 \%$ were reported among athletes by Pellicia et al. (2007) and Ma et al. (2006), respectively. Most minor ECG changes (sinus bradycardia, $\mathrm{R}$ or $\mathrm{S}$ wave, J-junction elevation and incomplete RBBB) were the result of structural and electrical remodelling of the heart to regular and sustained physical activity (Friedman 1985; Sokolow \& Lyon 1949).

The most frequent physiological ECG changes in this study were early repolarization, sinus bradycardia, and isolated LVH. The ECG patterns observed in this study were comparable to those reported by Wasse et al. (2018). Using the 'Seattle Criteria', the latter found early repolarization $(n=362 / 69.7 \%), \mathrm{LVH}(\mathrm{n}=183 / 35.3 \%)$ and sinus bradycardia ( $n=149 / 28.7 \%$ ) were the most frequent ECG changes. Higher rate of LVH reported by Wasse et al. (2018) could be because the study only involved men basketballers as compared to the current study which involved athletes of various sports that include both genders. Moreover, significantly higher LV mass was reported among male athletes involved in dynamic sport than women (Finocchiaro et al. 2017).

The current study also found physiological ECG changes occurs significantly more frequent in men than women. Our findings are consistent with that reported in previous studies. Significantly higher frequency of training related ECG changes including LVH, sinus bradycardia, first degree heart block, incomplete RBB, and $1^{\text {st }}$ degree AV block were reported in elite men than women athletes (Corîci et al. 2018; Finocchiaro et al. 2017; Wasfy et al. 2014). These findings supported the notion of gender related differences in physiological and electrical remodelling of the heart induced by sustained physical training. Although the exact underlying mechanism/s for this observation is not yet understood, it is hypothesised that variations in the level of circulating hormones (oestrogen in women and testosterone in men) are the key factors responsible for differences in cardiovascular responses to training. Hence, the role gender specific ECG criteria including relevant cut-off values need to be evaluated in future research.

Significantly more athletes of Chinese ethnicity had physiological ECG changes compared to other races. Higher proportion of athletes of Chinese ethnicity demonstrated sinus arrythmias, sinus bradycardia and LVH compared to athletes of another ethnicity. Our findings were consistent with that reported by $\mathrm{Ng}$ et al. (2011). In their analysis among 18,000 male conscripts undergoing preparticipation screening for the Singapore Armed Forces, higher prevalence of LVH was found among Chinese. Recent study involving 144,346 young male conscripts conducted by the Singapore Armed Forces. Sia et al. (2019) reported conscripts of Chinese ethnicity demonstrated significantly difference in several ECG characteristics including PR interval, QRS duration and QTcB compared to Malays and Indians. Significant difference in ECG patterns between ethnicity was also reported by previous studies (Di Paolo \& Pelliccia 2007; Papadakis et al. 2012). Di Paolo et al. (2012) reported significantly higher prevalence of first-degree AV block, LVH, ST-segment elevation, inverted T-waves and biphasic T waves among adolescent African soccer players compared to Caucasians. Moreover, convex (domed) shape ST-elevation was observed almost exclusively among African players. Although all athletes undergo similar process of training-related physiological and structural cardiac adaptation, the concentric cardiac remodelling is more prevalent among athletes of African background compared to other ethnicity (Riding et al. 2019). Differences in the ECG pattern across various ethnic background suggests genetic determinants of cardiac adaptation when exposed to regular physical training (Drezner et al. 2013a, 2013b; Ozo \& Sharma 2020).

The prevalence of abnormal ECG among Malaysia National Athletes was 4\%. Our finding is comparable to previous studies (Ma et al. 2007; Perrin et al. 2017). In a study among 351 young athletes using standardised ECG reporting criteria, Ma et al. (2007) reported ECG abnormalities (distinctly abnormal \& mildly abnormal) prevalence of $4.5 \%$ among 13 to 33 years old athletes. Slightly lower abnormal ECG prevalence of $2.8 \%$ was reported among Swiss elite athletes (14 years and older) using the Seattle ECG criteria. It should be noted that nearly all athletes in the latter study were Caucasian (99.7\%, n=288) (Perrin et al. 2017). In a contrary, higher prevalence of abnormal ECG (40\%) was reported among 1005 Italian athletes. Higher prevalence rate observed by Pelliccia et al. (2007) could be attributed to the difference in the criteria used to classify ECG patterns. Moreover, majority $(70 \%)$ of participants in their study were males.

Several limitations require to be addressed in this study. First, the study population included only elite athletes attending the NSI Clinic. Hence, the findings are not representative of the entire athletes in Malaysia encompassing all participation levels (e.g. amateur and semi-professional) and types of sports. Second, the nature of a cross-sectional study does not allow evaluation of ECG over time to ascertain how early ECG changes would occur. 
Third, all medical records reviewed did not include echocardiography, cardiac magnetic resonance imaging, genetic testing, and information on family screening.

\section{CONCLUSION}

The prevalence of abnormal ECG among Malaysian athletes of $4 \%$ was comparable with previous studies. Majority of Malaysia National Athletes had physiological adaptation ECG changes. The 3 most common physiological adaptation changes were early repolarization, sinus bradycardia, and isolated left ventricular hypertrophy. Physiological adaptation ECG changes was found to be significantly for prevalent in male gender and particularly of Chinese ethnic background. These information would facilitate the development of a specific guideline in interpreting ECG among Malaysian athletes.

\section{ACKNOWLEDGEMENTS}

The authors would like to acknowledge the support and assistance of Ms. Faliza Jaafar in data collection. We also acknowledge the National Sports Institute of Malaysia and University of Malaya for their support in the conduct of this study.

\section{REFERENCES}

BMJ Learning. ECG Interpretation in Athletes. https://learning. bmj.com/learning/course-intro/.html? courseId=10042239. Accessed on Jan 20, 2020.

Corîci, O.M., Mirea-Munteanu, O., Donoiu, I., Istrătoaie, O., Corîci, C.A. \& Iancău, M. 2018. Gender-related electrocardiographic changes in athletes. Current Health Science Journal 44(1): 29-33. https://doi.org/10.12865/ CHSJ.44.01.05.

Corrado, D., Basso, C., Pavei, A., Michieli, P., Schiavon, M. \& Thiene, G. 2006. Trends in sudden cardiovascular death in young competitive athletes after implementation of a preparticipation screening program. JAMA 296(13): 1593-1601. https://jamanetwork.com/journals/jama/ fullarticle/203513.

D'Silva, A. \& Sharma, S. 2014. Exercise, the athlete's heart, and sudden cardiac death. The Physician and Sports Medicine 42(2): 100-113. https://www.tandfonline.com/doi/ abs/10.3810/psm.2014.05.2062.

Department of Statistics Malaysia. 2019. Official Portal. Population Quick Info for 2019 by ethnicity. http://pqi.stats. gov.my/result.php?token=57501 aafee1719207693ff96cad1 b8cf. Accessed on Jan 20, 2020.

Di Paolo, F.M. \& Pelliccia, A. 2007. The "Athlete's Heart": Relation to gender and race. Cardiology Clinics 25(3): 383389. https://doi.org/10.1016/j.ccl.2007.06.010.

Di Paolo, F.M., Schmied, C., Zerguini, Y.A., Junge, A., Quattrini, F., Culasso, F., Dvorak, J. \& Pelliccia, A. 2012. The athlete's heart in adolescent Africans: An electrocardiographic and echocardiographic study. Journal of American College of Cardiology 59(11): 1029-1036. https://doi.org/10.1016/j. jacc.2011.12.008.

Drezner, J.A., Ackerman, M.J., Anderson, J., Ashley, E., Asplund, C.A., Baggish, A.L. Börjesson, M., Cannon, B.C., Corrado, D., DiFiori, J.P., Fischbach, P., Froelicher, V., Harmon, K.G., Heidbuchel, H., Marek, J., Owens, D.S., Paul, S., Pelliccia, A., Prutkin, J.M., Salerno, J.C., Schmied, C.M., Sharma, S., Stein, R., Vetter, V.L. \& Wilson, M.G. 2013a. Electrocardiographic interpretation in athletes: The 'Seattle criteria'. British Journal of Sports Medicine 47(3): 122-124. https://bjsm.bmj.com/content/47/3/122.short.

Drezner, J.A., Fischbach, P., Froelich, V., Marek, J., Pelliccia, A., Prutkin, J.M. Schmied, C.M., Sharma, S., Wilson, M.G., Ackerman, M.J., Anderson, J., Ashley, E., Asplund, C.A., Baggish, A.L., Börjesson, M., Cannon, B.C., Corrado, D., DiFiori, J.P., Harmon, K.G., Heidbuchel, H., Owens, D.S., Paul, S., Salerno, J.C., Stein, R., Vetter, V.L. 2013b. Normal electrocardiographic findings: Recognising physiological adaptations in athletes. British Journal of Sports Medicine 47(3): 125-136. https://bjsm.bmj.com/content/47/3/125.short.

Field, A. 2009. Discovering Statistics Using SPSS. 3rd ed. London: SAGE Publications Ltd.

Finocchiaro, G., Dhutia, H., D’Silva, A., Malhotra, A., Steriotis, A., Millar, L., Prakash, K., Narain, R., Papadakis, M., Sharma, R. \& Sharma, S. 2017. Effect of sex and sporting discipline on LV adaptation to exercise. JACC Cardiovascular Imaging 10(9): 966-972. https://www.sciencedirect.com/science/ article/pii/S1936878X16307379.

Friedman, H.H. 1985. Diagnostic Electrocardiography and Vectorcardiography. McGraw-Hill Companies. ht tp://books.google.com.my/books?id= ClsAAAAMAAJ\&hl=\&source $=\mathrm{gbs} \_$api.

Harmon, K.G., Asif, I.M., Klossner, D. \& Drezner, J.A. 2011. Incidence of sudden cardiac death in National Collegiate Athletic Association athletes. Circulation 123(15): 1594-1600. https://doi.org/10.1161/CIRCULATIONAHA.110.004622.

Karagjozova, I., Petrovska, S., Nikolic, S., Maleska-Ivanovska, V. \& Georgievska-Ismail, L. (2017). Frequency of electrocardiographic changes in trained athletes in the Republic of Macedonia. Open Access Macedonian Journal of Medical Sciences 5(6): 708-713. https://doi.org/10.3889/ oamjms.2017.174.

Lim, Z.L., Mokhtar, A.H. \& Jaffar, M.R. 2017. Pre-participation evaluation of Malaysian university athletes the importance of cardiovascular screening. Movement Health \& Exercise 6(2): 83-96.

Lisman, K.A. 2016. Electrocardiographic evaluation in athletes and use of the Seattle criteria to improve specificity. Methodist DeBakey Cardiovascular Journal 12(2): 81-85. https://doi. org/10.14797/mdcj-12-2-81.

Ma, J.Z., Dai, J., Sun, B., Ji, P., Yang, D. \& Zhang, J.N. 2007. Cardiovascular pre-participation screening of young competitive athletes for prevention of sudden death in China. Journal of Science and Medicine in Sport 10(4): 227-233. https://doi.org/10.1016/j.jsams.2006.07.001. 
Magalski, A., Maron, B.J., Main, M.L., McCoy, M., Florez, A., Reid, K.J., Epps, H.W., Bates, J. \& Browne, J.E. 2008. Relation of race to electrocardiographic patterns in elite American football players. Journal of American College of Cardiology 51(23): 2250-2255. https://doi.org/10.1016/j. jacc.2008.01.065.

Maron, B.J., Carney, K.P., Lever, H.M., Lewis, J.F., Barac, I., Casey, S.A. \& Sherrid, M.V. 2003. Relationship of race to sudden cardiac death in competitive athletes with hypertrophic cardiomyopathy. Journal of American College of Cardiology 41(6): 974-980. https://doi.org/10.1016/s07351097(02)02976-5.

Midi, H., Sarkar, S.K. \& Rana, S. 2013. Collinearity diagnostics of binary logistic regression model. Journal of Interdisciplinary Mathematics 13(3): 253-267.

Mitchell, J.H., Haskell, W., Snell, P. \& Van Camp, S.P. 2005. Task Force 8: Classification of Sports. Journal of American College of Cardiology 45(8): 1364-1367.

Ministry of Health Malaysia. Clinical Practice Guidelines on Management of Obesity 2004.

http://www.moh.gov.my/moh/resources/Penerbitan/CPG/ Endocrine/5a.pdf.

Ng, C.T., Chee, T.S., Ling, L.F., Lee, Y.P., Ching, C.K., Chua, T.S.J., Cheok, C. \& Ong, H.Y. 2011. Prevalence of hypertrophic cardiomyopathy on an electrocardiogram-based pre-participation screening programme in a young male South-East Asian population: Results from the Singapore Armed Forces Electrocardiogram and Echocardiogram screening protocol. Europace 13(8): 883-888.

Ozo, U. \& Sharma, S. 2020. The impact of ethnicity on cardiac adaptation. European Cardiology Review 15: e61. https://doi. org/10.15420/ecr.2020.01.

Papadakis, M., Wilson, M.G., Ghani, S., Kervio, G., Carre, F. \& Sharma, S. 2012. Impact of ethnicity upon cardiovascular adaptation in competitive athletes: Relevance to preparticipation screening. British Journal of Sports Medicine 46(Suppl. 1): i22-i28. https://doi.org/10.1136/ bjsports-2012-091127.

Pelliccia, A., Culasso, F., Di Paolo, F.M., Accettura, D., Cantore, R., Castagna, W., Ciacciarelli, A., Costini, G., Cuffari, B., Drago, E., Federici, V., Gribaudo, C.G., Lacovelli, G., Landolfi, L., Menichetti, G., Atzeni, U.O., Parisi, A., Pizzi, A.R., Rosa, M., Santelli, F., Santilio, F., Vagnini, A., Casasco, M. \& Di Luigi, L. 2007. Prevalence of abnormal electrocardiograms in a large, unselected population undergoing pre-participation cardiovascular screening. European Heart Journal 28(16): 2006-2010. https:// academic.oup.com/eurheartj/article/28/16/2006/493352.

Perrin, T., Trachsel, L.D., Schneiter, S., Menafoglio, A., Albrecht, S., Pirrello, T., Eser, P., Roten, L., Gojanovic, B. \& Wilhelm, M. 2017. Prevalence of abnormal electrocardiograms in Swiss elite athletes detected with modern screening criteria. Swiss Medical Weekly 146: w14376. https://boris.unibe.ch/ id/eprint/110459.

Rawlins, J., Carre, F., Papdakis, M., Edwards, C.P., Chandra, N. \& Sharma, S. 2009. Ethnic differences in physiological cardiac adaptation to intense physical exercise in highly trained female athletes. Circulation 121(9): 1078-1085. https://heart. bmj.com/content/95/Suppl_1/120.abstract.
Riding, N.R., Sharma, S., McClean, G., Adamuz, C., Watt, V. \& Wilson, M.G. 2019. Impact of geographical origin upon the electrical and structural manifestations of the black athlete's heart. European Heart Journal 40(1): 50-58.

Sia, C., Dalakoti, M., Tan, B.Y.Q., Lee, E.C.Y., Shen, X., Wang, K., Lee, J.S., Arulanandam, S., Chow, W., Yeo, T.J., Yeo, K.K., Chua, T.S.J., Tan, R.S., Lam, C.S.P. \& Chong, D.T.T. 2019. A Population-wide study of electrocardiographic (ECG) norms and the effect of demographic and anthropometric factors on selected ECG characteristics in young, Southeast Asian males - results from the Singapore Armed Forces ECG (SAFE) study. Annals of Noninvasive Electrocardiology 24(3): e12634. https://onlinelibrary.wiley.com/doi/pdf/10.1111/ anec. 12634

Sokolow, M. \& Lyon, T.P. 1949. The ventricular complex in left ventricular hypertrophy as obtained by unipolar precordial and limb leads. American Heart Journal 37(2): 161-186. https://www.sciencedirect.com/science/article/ pii/0002870349905621.

Waase, M.P., Mutharasan, R.K., Whang, W., DiTullio, M.R., DiFiori, J.P., Callahan, L., Mancell, J., Phelan, D., Schwartz, A., Homma, S. \& Engel, D.J. 2018. Electrocardiographic findings in National Basketball Association athletes. JAMA Cardiology 3(1): 69-74.

Mohamad Shariff A Hamid*, Zulkarnain Jaafar \& Samihah Abdul Karim

Sports Medicine Unit

Faculty of Medicine

University of Malaya

50603 Kuala Lumpur, Federal Territory

Malaysia

Mohamad Shariff A Hamid*, Ahmad Munawwar Helmi Salim \& Kamarul Hashimy Hussein

National Sports Institute of Malaysia

Bukit Jalil

57000 Kuala Lumpur, Federal Territory

Malaysia

Sazlina Shariff Ghazali

Department of Family Medicine

Faculty of Medicine and Health Sciences

Universiti Putra Malaysia

43400 UPM Serdang, Selangor Darul Ehsan

Malaysia

Sazlina Shariff Ghazali

Malaysian Research Institute on Ageing

Universiti Putra Malaysia

43400 UPM Serdang, Selangor Darul Ehsan

Malaysia

*Corresponding author; email: ayip@um.edu.my

Received: 20 January 2020

Accepted: 7 March 2021 